\title{
AM2016 Special Issue \\ Trust in Financial Services: The Influence of Demographics and Dispositional Characteristics
}

\section{ABSTRACT}

So far very little attention has been paid to examining consumer perceptions of trust from an interdisciplinary perspective. The purpose of this study is to examine how consumer trusting belief and disposition to trust within the financial services sector vary on the basis of individual demographic differences in trust. The research provides new insights into how consumers with higher dispositional trust have higher institutional trust and higher trusting belief; and how consumers' trusting belief significantly differs according to their demographic background in terms of age, marital status, ethnicity and gross annual income. The findings offer useful insights for the managers in financial institutions to carefully consider the impact of the influence of these individual differences on consumer behaviour in order to serve the needs of consumers in their target market and be able to design financial products and develop trust building strategies to attract and retain them. They also call for the action of the regulators and the financial institutions to play their part in building strong institutional systems that contribute to engendering higher levels of consumer trust.

Keywords: Demographics, dispositional characteristics, interpersonal trust, institutional trust, financial services.

\section{INTRODUCTION}

Trust has been found to be at the heart of the marketing concept (Arnott, 2007) and works as 'glue' (Berry, 1995) in any relationships including those between sellers and buyers. Although extensive scholarly work has been done (Ping Li, 2007) on trust in the domain of organisational management and strategic alliance (Gambetta, 1988; Inkpen and Currall, 2004; Koza and Lewin, 1998; Rousseau et al., 1998; Zaheer and Harris, 2006), relatively little attention has been paid to this construct in the marketing 
domain (Arnott, 2007) with the result that much less is known about trust in the context of financial services. With the exception of empirical work mostly focusing around the attributes of trustees i.e. trustworthiness and measurement of trust in various financial institutions in general (Ennew and Sekhon, 2007, Ennew et al, 2011) or cognitive and affective trust in particular (Sekhon et al, 2014), as well as the testing of interdisciplinary trust theories within the financial services context (Sekhon et al, 2013; Moin et al, 2015; Moin et al, 2016), no research has been found that has examined the influence of demographic differences on consumer perceptions of trust from an interdisciplinary perspective in this context. Marketers need to understand the influence of demographic differences on consumers' perception of trust in financial services so that they can serve the needs of each segment of consumers and be able to develop effective strategies to attract and retain them. Therefore, this study aims to understand whether there are individual differences in consumer perceptions of trusting belief, institutional trust and dispositional trust based on demographic characteristics such as gender, age, marital status, ethnicity and gross annual income. The paper starts with a brief literature review on trust research in management and related disciplines to justify the rationale for this research before focusing on the interdisciplinary perspectives of trust with particular attention to a number of trust constructs rooted in psychology, sociology and economics. Next the research methodology is described followed by the analysis and discussion of results. Finally conclusions are drawn and implications of this research outlined as well as directions for future research.

\section{LITERATURE REVIEW}

\section{The demographic analysis of trust in financial services}

The research on trust dates back to 1958 in psychology with the early work of Deutsch (1958) on conflict resolution. The next two notable research studies in psychology covered the aspects of interpersonal trust by Rotter (1967) and Zand (1972). However, among the early studies the mostly cited research in sociology was on trust and power by Luhmann (1979). Management researchers became interested in the topic in the mid-80s and Dwyer et al's (1987) research looking at the interpersonal trust relationships between buyers and sellers was found to be the most notable study (Arnott, 2007). Some of the widely cited studies in management in the 
early and mid-90s examined trust between business and marketing research agencies (Moorman et al, 1992 and 1993); trust in relationship marketing (Morgan and Hunt, 1994) and cognitive and affective trust (McAllister, 1995). Thereafter trust research has attracted a lot of interest in the fields of management, organisational behaviour and business ethics with numerous articles published about online or system security (Arnott, 2007). In addition, trust has been conceptualised from an interdisciplinary perspective (Mayer et al, 1995; McKnight et al, 1998; McKnight and Chervany, 2001-2002; McKnight et al, 2002; Tan and Sutherland, 2004; Moin et al, 2015; Moin et al, 2016). However, trust in the services context in general and financial services in particular remains under-researched (Tyler and Stanley, 2007). So far, very little attention has been paid to the influence of demographic differences on consumer trust. Nienaber et al (2014) has given a brief account of all the major trust research in the context of financial services sector, which also do not contain any research that involved demographic analysis of trust in the context of financial services sector. The limited research involving demographic analysis of trust is further evidenced through a recent search of outputs generated by the 'Business Source Complete' database using keyword(s) 'trust', 'demographic(s)', and 'financial services' within the abstract of the documents published between 1981 and February 2017. The search of keyword 'trust' within the abstract resulted 76,757 documents of which 39,530 are scholarly publications including peer reviewed journal articles. The search of keywords 'trust' and 'financial services' resulted 843 documents of which 421 are scholarly publications. The search of keywords 'trust', 'demographic(s)', and 'financial services' resulted only 13 documents of which 7 are scholarly publications whereas the keywords 'trust' and 'demographics' resulted 417 documents of which 138 are scholarly publications. This also shows that the demographic analysis of the level of trust in case of financial services is inadequate yet important particularly for the managers and regulators. Such types of studies have been conducted in other sectors and the empirical findings suggest that the level of trust varies based demographic differences. Higher levels of trust propensity have been found in individuals with high income (Alesina and La Ferrara, 2002), higher educational level (Uslaner, 2002), and gender (Feingold, 1994). Feingold (1994) research focused on examining gender differences in personality where males were found more assertive and with slightly higher self-esteem than females but females were higher in trust, extraversion, anxiety and tender-mindedness. Alesina and La Ferrara (2002) research investigated how trust 
on each other is influenced by individual and community characteristics, where individual characteristics refer to age, gender and race. Another research conducted by Christensen and Laegreid (2002) found that trust in government is also influenced by demographic factors such as age, education and occupation. Therefore, our research is particularly interested in a detailed demographic analysis of the interdisciplinary perspective of trust in the context of financial services sector. To be more specific, this study addressed the following two research questions:

RQ1: To what degree do consumers' general disposition to trust and their trust in the system (i.e. institutional trust) impact on their level of trusting belief for their own bank?

RQ2: Whether the financial services' consumers differ in their perception of trusting belief for their own bank based on demographic factors such as marital status, age, ethnicity, gross annual income, gender and so forth?

\section{Interdisciplinary perspective of trust}

Trust is a multidimensional construct. A wide range of interdisciplinary literature conceptualise trust as (a) a set of beliefs or expectations about the motives or future intentions of trustees (Sitkin and Roth, 1993); (b) willingness of trustors to rely/ depend on trustees (Doney et al, 1998; Mayer et al, 1998) or as behavioural intention, which comes from the willingness of trustors to use their expectations or belief (Luhmann, 1979; McAllister, 1995 and Scott, 1995); and (c) trust related behaviour or taking actions, which involve risk-taking (Moorman et al, 1992) and will increase the vulnerability of one person to another (Deutsch, 1962). The major constructs of trust which have been mostly referred in the management research originate from psychology, sociology, economics, and social psychology (McKnight et al, 1998), offering important distinctive insights on trust, which includes three major categories of trust such as interpersonal, institutional and disposition trust (McKnight and Chervany, 2001-2002) and a number of interdisciplinary trust constructs such as trusting belief, trusting intention, structural assurance, situational normality, faith in humanity and trusting stance (McKnight et al, 2002). 
Trusting belief is one of the most important antecedents of trusting intention, and concerns the belief of one about another based on the cognitive belief about that person (Bromiley and Cummings, 1995; Gabarro, 1978) and the person's emotional security about those beliefs. Trusting belief is both person and situation-specific (McKnight et al, 1998), meaning that one person believes that the other person is trustworthy in a specific situation rather than in a broad range of situations. Furthermore, trusting belief depends on trustworthiness, which includes attributes like competence, benevolence, honesty, predictability and so forth (Mayer et al, 1995; Tan and Sutherland, 2004; McKnight et al, 1998; McKnight and Chervany, 2001-2002). In the context of financial services sector Ennew and Sekhon (2007) and Ennew et al, (2011) identified five drivers for organisational trustworthiness (i.e. integrity and consistency, concern and benevolence, shared values, expertise and competence and communication), which have subsequently been used by the researchers to measure trusting belief for financial services consumers (Moin et al, 2015).

The concept of institutional trust, also known as system trust, comes from sociology and is a two-dimensional construct: structural assurance and situational normality (McKnight et al, 1998). Institutional trust assumes that situations or environmental setting impacts on the outcome of an endeouver within the situation and thereby influence trust. This construct is influenced by the situational attributes (i.e. structural assurance) rather than human traits (i.e. trustworthiness of trustees) and the perception that the situation is normal (i.e. situational normality). Therefore, it is situationspecific but also interpersonal (Chervany, 2001-2002). When structures, situations, roles and so forth provide assurance of a successful outcome, thereby resulting in a sense of structural assurance and situational normality, people find it easier to trust the organisation. The robustness of the structures: regulatory, legal, technical environment and so on provides confidence to trust (McKnight and Chervany, 2002). This two-dimensional construct comprising structural assurance and situational normality (McKnight et al, 1998) is particularly significant in the context of financial services sector given that the financial products and services are complex and risk perceptions in this sector are high. 
Dispositional trust is a two-dimensional construct and these dimensions are faith in humanity and trusting stance. Stems from psychology and economics, essentially dispositional trust refers to peoples' disposition to trust others; and advocates that peoples' tendency to trust in general over a broad range of situations and persons (McKnight et al, 1998) is driven by the personality-based traits they develop through their life-experience (Tan and Sutherland, 2004). Therefore, families, elementary educational institutions and the society at large, where peoples' life-experiences come from has significant role in shaping their perceptions about others and thereby their disposition to trust others. Although there are plenty of theories on personality traits, the widely used 'big five personality traits' theory (McCrae et al, 1989) describes a person's personality through five factors: extraversion, neuroticism, conscientious, openness to experience, and agreeableness. 'Faith in humanity' refers to "the extent to which one believes that nonspecific others are trustworthy" (McKnight et al, 1998, p.478) whereas 'trusting stance', drawn from calculative economic-based research stream, refers to an assumption that believing others and depending on them rather than not depending on them at all will lead to a superior outcome irrespective of people's perception about others. Faith in humanity contributes towards positive perception about others but trusting stance contributes to depend on others as a choice or strategy of trustors.

\section{RESEARCH METHOD}

\section{Sample and data collection}

To collect data for the purpose of this research a quantitative method was employed and a paper-based survey questionnaire was used to collect data. For ease of access and pragmatic reasons a convenience sample was drawn from UK employees of a multinational corporation having operations within 70 countries in the world including the major cities of the UK. With the support of the managers and customer service representatives and using internal mails and snowballing technique 420 paperbased questionnaires were distributed to the employees working in various branches located in some of the major UK cities. The questionnaire contained instructions, asking the respondents to indicate to what extent they agree or disagree with the statements (i.e. the measurement variables) in relation to their main bank. Within the questionnaire brief, the main bank was defined as the bank they use most of the time. 
To identify their demographic background, information on gender, marital status, age range, ethnicity, gross annual income and so forth were collected. Of 420 questionnaire, 301 were returned of which 300 were usable, resulting in a response rate of $71.43 \%$. Table 1 summarises profile of the sample.

\section{Insert "Table 1: Summary of Sample Profile" here}

\section{Measures}

The measurement scales (Table 2) that were used to measure the various dimensions of interpersonal trust, institutional trust and dispositional trust have been adopted and developed from well-established measurement scales. The measures for the dimensions of institutional trust such as structural assurance and situational normality and for the dimensions of dispositional trust such as faith in humanity and trusting stance have been developed from the interdisciplinary literature on trust (McKnight et al, 1998; McKnight and Chervany, 2001-2002; Mayer et al, 1995). A robust scale development methodology has been followed for this - however, the process of the scale development is beyond the scope of this paper. The measures for the five dimensions of trusting belief such as integrity and consistency, concern and benevolence, shared values, expertise and competence, and communication have been replicated from Ennew et al's (2011) trust index. Since consumers trusting belief in financial services is measured by the organisational trustworthiness and Ennew et al's (2011) trust index was found to be a well-constructed validated measurement with strong construct validity and widely in used financial services research, this was done to avoid gap between conceptualisation and operationalisation (McEvily and Tortoriello, 2011). Prior to the main study all the scales were tested and purified through pilot testing.

\section{Insert "Table 2: Measurement Scale" here}




\section{DATA ANALYSIS AND RESULTS}

\section{Exploratory and confirmatory factor analyses}

To test the factor structure of trusting belief, trusting intention, institutional trust and dispositional trust, and identify poorly-performing items and test scale reliability, Exploratory Factor Analysis (EFA) was conducted followed by Confirmatory Factor Analysis (CFA) to examine uni-dimensionality and validity (Garbing and Hamilton, 1996; Cadogan et al, 2009) using LISREL 8.80. Exploratory Factor Analysis was completed using SPSS Principal Component Analysis using a standard Varimax with Kaiser Normalisation Rotation Model with a cut-off point of 0.50 . Out of fifty variables used to measure the ten sub-constructs/dimensions of the four main constructs, only six variables were dropped (i.e. five due to cross-loadings and one due to an item factor loading of less than 0.50 ). The summary of the results of EFA including the correlation coefficients between variables, factor loadings and measurement properties are summarised in Table 3.

Insert "Table 3: Summary of the Result of EFA" here

The factor solutions obtained through EFA was used for CFA using Lisrel to further confirm the factor structure and to measure the reliability and validity of the measurement scales. Table 4 presents the summary of the results of CFA including the indices for goodness of fit of the model and discriminant validity of the scales (Cadogan et al, 2009).

Insert “Table 4: Construct Correlation and Measurement Properties” here

\section{Model fit and validity of the measurement scales}

The output generated through CFA, support that the model has achieved a reasonably good measurement fit to data on the basis of commonly used fit indicators. The value of RMSEA is $0.077(<0.8)$ and the values for CFI, IFI and NNFI are all above $0.9-$ all of which support a good measurement fit (Hu and Bentler, 1995; Hooper et al, 2008). The ratio of the Chi-Squared $(\chi 2)$ to degrees of freedom (df) is 2.63 (within 1 to 3 ) provides further evidence to the model fitness (Carmines and Mclver, 1981). The 
measurement scales of the constructs achieved Composite Reliability (CR) greater than the recommended threshold of 0.7 (Nunnally, 1978) and thereby also greater than the recommended threshold of 0.6 (Bagozzi and Yi, 1988). There is also strong support in favour of the discriminant validity of the measures as the Average Variance Extracted (AVE) for all the constructs are also greater than 0.5 (Fornell and Larcker, 1981) and the root square of Average Variance Extracted (AVE) for all the scales is greater than the correlation between those variables (Cadogan et al, 2009). All these findings confirm that the convergent and discriminant validity of the measures have been achieved.

\section{Development of high-trust and low-trust clusters}

In order to investigate the impact of the consumer characteristics of a general disposition to trust and trust in the system (i.e. institutional trust) have a notable impact on trusting belief in the respondents main bank, cluster analysis was used to create a high and low trust cluster for both dispositional trust and institutional trust. Cluster analysis is a common, respected and well-used method in marketing research for generating empirical groupings of individuals for use in further analysis (Punj and Stewart, 1983). As explained above, dispositional trust comprises of two elements, faith in humanity and trusting stance - and their measures are shown in Table 2. Factor means for these two measures were then used to produce a two-factor solution. Results are shown in Table 5. Data indicate that the mean scores for 'cluster 1' are significantly lower than for 'cluster 2' for both sub-dimensions of dispositional trust. Therefore, 'cluster 1' is the 'LOW general disposition to trust cluster' and 'cluster 2' is the 'HIGH general disposition to trust cluster'. Institutional, or system trust also has two elements, namely structural assurance and situational normality and measures for these constructs are also shown in Table 2. Data for the two factor means for these items also indicate that 'cluster 1' is the low trust cluster, whilst 'cluster 2' is the high trust cluster, as illustrated in Table 5. Thus, 'cluster 1' is the 'LOW trust in the institutional trust group', whilst 'cluster 2' represents those with relatively 'HIGH trust in the system (i.e. with High institutional trust)'. The groups produced by the cluster analysis were then used in subsequent analysis.

\section{Insert "Table 5: Measurement of Trust" here}




\section{General disposition to trust and trusting belief}

Firstly, an independent samples t-test was employed to confirm whether a general disposition to trust manifested itself in a higher degree of trusting belief in one's own bank. Whilst it might be expected ex-ante that a general tendency to give people the benefit of the doubt and to trust media such as TV and newspapers would transfer to specific sectors, it is also the case that banking and financial services holds particular challenges for consumer, since this sector has been the subject of a number of scandals in the recent past and is generally considered a very low trust environment. Such factors could easily dominate anyone's general disposition to trust, meaning that trusting belief in one's bank is low regardless of general dispositional trust. Results are presented in Table 6 and show that for all five dimensions of trusting belief, the mean score for the high general disposition to trust cluster is significantly higher than that for the low general disposition to trust cluster. Therefore, results confirm unequivocally that a general propensity to trust does transfer effectively to the financial services sector.

Insert "Table 6: General Disposition to Trust and Trusting Belief" here

\section{Trust in the system (institutional trust) and trusting belief}

Although it might be reasonably assumed that trust in the system that supports financial institutions would translate into higher levels of trust for a user's bank, it is not necessarily the case. Previous research (Grayson et al, 2008) has shown a marked difference between "broad scope" trust (equivalent to trust in the system) and "narrow scope" trust (trust in a particular institution). Therefore, an independent sample t-test was employed to check whether higher overall trust in the system manifests itself in higher levels of trust in the respondent's bank. Results are shown in Table 7. Results indicate that the high trust in the system cluster does indeed have significantly higher levels of trusting belief across all dimensions. Whilst not entirely surprising, this result offers re-assurance that general system trust does lead individuals to trust their own bank to a greater degree.

Insert "Table 7: Trust in the System (Institutional Trust) and Trusting Belief" here 


\section{Gender and trusting belief in financial services}

This study also tests the impact of a number of demographic variables on levels of trusting belief, using independent samples t-tests for dichotomous categories and ANOVA where there are more than two categories. From an interdisciplinary perspective, as trusting belief is both person and situation specific (McKnight et al, 1998), our particular point of interest here is to test whether consumers' demographical characteristics influence their trusting belief in the context of the financial services sector. The t-test for gender is shown in Table 8 and results indicate that there are no significant differences in trusting belief between males and females.

\section{Insert "Table 8: Gender and Trusting Belief” here}

\section{Age and trusting belief in financial services}

The results of the ANOVA for conducting this test are presented in Table 9 and reveal that among various age groups there are differences in their perception of integrity and consistency $(F=4.037$, Sig $=0.019)$, shared values $(F=5.815, \operatorname{Sig}=0.003)$ and communication $(\mathrm{F}=3.511$, $\mathrm{Sig}=0.031)$, which are statistically significant but the differences among various age groups in their perception of concern and benevolence $(F=2.185, \operatorname{Sig}=0.114)$ and expertise and competence $(F=0.785, \operatorname{Sig}=0.457)$ are not statistically significant. Thus, on balance, there is reasonable support for the contention that there is variation in the level of trusting belief on account of age. Post hoc analysis ${ }^{1}$ indicates that those in the older age group (35 and older) are significantly more trusting than others.

\section{Insert "Table 9: Summary of Output of ANOVA: Age and Trusting Belief" here}

\section{Marital status and trusting belief in financial services}

The results of ANOVA (Table 10) reveal that people with different marital status differ significantly in their perception of integrity and consistency $(F=4.876$, Sig $=0.008)$, concern and benevolence $(\mathrm{F}=4.474$, Sig $=0.012)$ and expertise and competence $(\mathrm{F}=4.881$, Sig $=0.008)$ but they do not significantly differ in their

1 Post Hoc analyses are not presented in the paper in the interests of clarity and brevity, but are available from the authors on request 
perception of shared values $(\mathrm{F}=1.269, \mathrm{Sig}=0.283)$ and communication $(\mathrm{F}=2.059$, Sig $=0.130$ ). Again, on balance, there is reasonable evidence that some elements of trusting belief vary significantly by marital status. Post-hoc analysis indicates that where there are differences, divorced people have significantly higher levels of trusting belief than others in the sample.

Insert "Table 10: Summary of Output of ANOVA: Marital Status and Trusting Belief" here

\section{Ethnicity and trusting belief in financial services}

The results of ANOVA (Table 11) reveal that people with different ethnic background differ significantly in their perception of integrity and consistency $(F=4.900$, Sig $=0.008)$, concern and benevolence $(\mathrm{F}=4.691$, $\mathrm{Sig}=0.010)$ and shared values $(\mathrm{F}=$ 3.313, Sig $=0.038$ ) but they do not significantly differ in their perception of expertise and competence $(F=0.786, \operatorname{Sig}=0.457)$ and communication $(F=0.549, \operatorname{Sig}=0.578)$. Post-hoc analysis indicates that where there are differences the main pattern is that South Asian respondents are most trusting, followed by white respondents and black and other respondents are the least trusting.

\section{Insert "Table 11: Summary of Output of ANOVA: Ethnicity and Trusting Belief" here}

\section{Income and trusting belief in financial services}

The results of ANOVA (Table 12) reveal that people with different gross annual income differ significantly in their perception of shared values $(F=4.489$, Sig $=0.012)$ and communication $(\mathrm{F}=3.967, \mathrm{Sig}=0.020)$ but they do not significantly differ in their perception of integrity and consistency $(\mathrm{F}=1.286$, Sig $=0.278)$, concern and benevolence $(F=1.708$, Sig $=0.183)$ and expertise and competence $(F=2.245$, Sig $=0.108$ ). Therefore, there is some evidence to suggest differences according to income, but less than in the case of other demographic factors. Post-hoc analysis shows that trust levels generally increase with income.

\section{Insert "Table 12: Summary of Output of ANOVA: Income and Trusting Belief \\ " here}




\section{DISCUSSION AND IMPLICATIONS}

This research offers novel insights through empirically testing the relevance of the interdisciplinary theories of dispositional trust, institutional trust and trusting belief (McKnight et al, 1998; McKnight and Chervany, 2001-2002; McKnight et al, 2002; Mayer et al, 1995) in the context of the financial services sector. A comprehensive investigation of the trust literature postulates that this research is the first study that finds empirical evidence suggesting consumers' disposition to trust in terms of faith in humanity and trusting stance along with their perception of institutional trust in terms of structural assurance and situational normality (McKnight et al, 1998; McKnight and Chervany, 2001-2002; McKnight et al, 2002) are transferred to the financial services sector. Consumers' disposition to trust has also found to be linked to their institutional trust. The findings of this research demonstrates that consumers of financial services can be categorised based upon their disposition to trust i.e. consumers with higher and lower dispositional trust. These segmentations of consumers of the financial services are congruent with the segmentations based on their perceptions of institutional trust: structural assurance and situational normality. The study also reveals that consumers with higher dispositional trust have higher trusting belief than the consumers with lower dispositional trust; and consumers with higher institutional trust have higher trusting belief than the consumers with lower institutional trust - thereby also validating the theoretical links between trusting belief, dispositional trust and institutional trust.

This study also underscores that the difference between two above groups are statistically significant. Thus, this research highlights the importance of institutional trust and dispositional trust to improve the overall trusting belief of the consumers. While many research focus on the trustworthiness (Ennew and Sekhon, 2007; Ennew et al, 2011), cognitive and affective trust (Sekhon et al, 2013), this research calls for the attention of the regulators and financial institutions to the importance of building a sound and strong financial structure to influence consumers' trusting belief. In case of financial services the perception of strong structural assurance can be promoted through enforcing appropriate regulatory regimes, redress mechanisms, compensation and deposit guarantee schemes and so forth (Moin et al, 2015). Therefore, this 
research contributes through projecting the relevance of the interdisciplinary theories of trust in the context of financial services sector.

Furthermore, trusting belief of the consumers significantly differs due the differential demographic backgrounds such as age, marital status, ethnicity and gross annual income as found by this study contributes to the intersection of relationship marketing (Free, 1996; de Chernatony et al, 1999; Berry, 2000; Elliott and Percy, 2007), services marketing (Elliott and Percy, 2007) and interpersonal trust (McKnight et al, 1998). This is because the findings of the study suggest that the financial services institutions should carefully consider the demographic backgrounds of their consumers to better understand their needs and wants. The demographic analysis of consumers' perception of trusting belief reveals some interesting findings that consumers of the age of 35 years and older are significantly more trusting than others; divorced people have significantly higher levels of trusting belief than others; consumers with South Asian backgrounds are most trusting, followed by white and black and others; and level of trust levels generally increase with the income of the consumers. Nonetheless, the findings indicate that there are no significant differences in trusting belief between males and females.

This study provided some significant implications for the managers and regulators within the financial institutions. First, the concept of higher and lower dispositional trust will help marketing managers in segmentation, targeting and positioning and product development strategies. While doing so the managers in financial institutions should carefully ponder on the demographic differences amongst their consumers and design the product ranges, which meet the needs and demands of each group of customers. Thus, the financial institutions will be more effective in devising the overall marketing strategies which are more conducive to fostering overall consumer perception of trust in financial services. This also means that the financial service providers should have a wide range of products to support the diverse needs of each segment of consumers. Second, the study calls for the actions of the regulators and the financial institutions to build strong and credible institutional systems that contribute towards higher consumer trust and continue to provide their consumers with a sense of strong structural assurance and situational normality. This is where media has an important role to play in spreading more good-news stories and narratives, which will 
contribute towards consumers' perception of situational normality and thereby contribute to their trusting belief. Third, since the family, elementary educational institutions and society have a significant impact on people's disposition to trust, this research highlights the role of the families, elementary educational institutions and the society as a whole to positively influence all aspects of trust through influencing peoples' disposition to trust.

\section{LIMITATIONS AND FUTURE RESEARCH DIRECTIONS}

Although the study has made some valuable contributions to both theories and practice, it is not completely free from limitations. The study gathered cross-sectional data with a comparatively small sample size than some of the funded research with access to a large and representative sample. From a sceptical angle this may raise some concern about the generalizability of the findings. However, the fundamental outcome of this study is to understand the importance of consumers' demographics and the dispositional characteristics on their perception of trusting belief - particularly in the context of financial services sector and there is no reason as to why future research cannot be conducted with a larger sample size and more representative sample. We believe our research has set the ground to understand consumers' trusting belief from the demographic perspective and further in-depth qualitative research has the potential to unveil the innate reasons behind some of the findings. This will be particularly beneficial for the financial institutions to design their products and services more effectively to meet the needs of diverse group of customers. Therefore, the future qualitative research has the potential to develop new theories within the cross-sections of trust, services and relationship marketing in relation to consumers' demographics and their disposition to trust.

\section{REFERENCES}

Alesina, A. \& La Ferrara, E. (2002) Who trusts others? Journal of Public Economics, 85 (2): 207-234.

Arnott, D. C. (2007) Trust - current thinking and future research, European Journal of Marketing 41 (9/10): $981-987$.

Bagozzi, R. P. and Yi, Y. (1988) On the evaluation of structural equation models, Journal of Academy of Management Science 16 (1): 74-94. 
Berry, L. (1995) Relationship marketing of services - Growing interest, emerging perspectives, Journal of the Academy of Marketing Science 23 (4): 236 -245.

Berry, L. L. (2000) Cultivating service brand equity, Journal of the Academy of Marketing Science 28 (1): 128-137.

Bromiley, P. and Cummings, L.L. (1995) Organizations with trust, In R. Bies, R. Lemicki and B. Sheppard (Eds.), Research in Negotiations. 5th Eds., Greenwich, CN: JAI Press

Cadogan, J.W., Lee, N., Tarkiainen, A. and Sundqvist, S. (2009) Sales manager and sales team determinants of sales person ethical behaviour. European Journal of Marketing 43 (7/8): $907-937$.

Carmines, E.G. and McIver, J.P. (1981) Analyzing models with unobserved variables, In Bohrnstedt, G.W. and Borgatta, E.F. (Eds), Social Measurement: Current Issues, Beverly Hills, CA: Sage, pp. 63-115

Christensen, T. and Laegreid, P. (2002) Trust in Government - the Relative Importance of Service Satisfaction, Political Factors and Demography, Working Paper 18 - 2002, presented at the Conference of the European Group of Public Administration, 4 -7 September 2002, Potsdam, Germany - group on Quality, Satisfaction and Trust in Government, pp. 1-35.

Deutsch, M. (1958) Trust and Suspicion, Journal of Conflict Resolution 2:

$265-279$.

Deutsch, M. (1962) "Cooperation and Trust: Some theoretical notes", NebrasKa Symposium on Motivation, pp. 275 -320. Lincoln: Nebraska University Press

de Chernatony, L. (1999) Brand management through narrowing the gap between brand identity and brand reputation, Journal of Marketing Management 15 (1-3): 157-179.

Doney, P. M., Cannon, J. P., and Mullen, M. R. (1998). "Understanding the influence of national culture on the development of trust", Academy of Management Review, Vol. 23, pp.601 -620

Dwyer, F. R., Schurr, P.H. and Oh, S. (1987) Developing buyer-seller relationships, Journal of Marketing 51(2): 11- 27.

Elliott, R. and Percy, L. (2007) Strategic Brand Management. New York: Oxford University Press Inc.

Ennew, C. and Sekhon, H. (2007) Measuring trust in financial services: the trust index. Consumer Policy Review 17 (2): 2-8.

Ennew, C., Kharouf, H., and Sekhon, H. (2011) Trust in UK financial services: A longitudinal analysis. Journal of Financial Services Marketing, 16 (1): 65-75.

Feingold, A. (1994) Gender Differences in Personality: A Meta-Analysis, Psychological bulletin, 116 (3): $429-456$.

Free, C. (1996) Building a financial service brand you can bank on. The Journal of Brand Management, 4 (1): 29-34. 
Fornell, C. and Larcker, D. F. (1981) Evaluating structural equation models with unobservable variables and measurement error. Journal of Marketing Research 18 (1): 39-50.

Gabarro, J. J. (1978) The development of trust, influence, and expectations. In Athos, A. G. \& Gabarro, J. J. (Eds.), Interpersonal behavior: Communication and understanding in relationships. Englewood Cliffs, NJ: Prentice-Hall, pp. 290 -303.

Gambetta, D. (1988) Can we trust? In Gambetta, D. (Ed.), Trust: Making and breaking cooperative relations. New York: Blackwell, pp. 213-237.

Gerbing, D. W. and Hamilton, J. G. (1996) Viability of exploratory factor analysis as a precursor to confirmatory factor analysis. Structural Equation Modelling 3 (1): 62-72.

Grayson, K, Johnson, D and Chen D-F R (2008) Is Firm Trust Essential in a Trusted Environment? How Trust in the Business Context Influences Customers. Journal of Marketing Research: April 2008, Vol. 45, No. 2, pp. 241-256.

Hu, L. and Bentler, P.M. (1995), Evaluating model fit, In Hoyle, R.H. (Ed.), "Structural Equation Modeling: Concepts", Issues, and Applications, Sage, Thousand Oaks, CA, pp. 7699.

Hooper, D., Coughlan, J. and Mullen, M. R. (2008) Structural Equation Modelling: Guidelines for Determining Model Fit, The Electronic Journal of Business Research Methods $6(1): 53-60$.

Inkpen, A. C. and Currall, S. C. (2004) The coevolution of trust, control, and learning in joint ventures. Organization Science 15: 586 - 599.

Koza, M. P. and Lewin, A. Y. (1998) The coevolution of strategic alliances. Organisation Science 9: $255-265$.

Luhmann, N. (1979) "Trust and power", New York: Wiley

Mayer, R.C., Davis, J.H. and Schoorman, F.D. (1995) An Integrative Model of Organizational Trust, Academy of Management Review, 20 (3): 712.

McAllister, D, J. (1995) Affect and cognition-based trust as foundations or interpersonal cooperation in organizations, Academy of Management Journal 38: 24-59

McCrae, Robert R. and Paul T. Costa, Jr. (1989), "The Structure of Interpersonal Traits: Wiggins's Circumplex and Five-Factor Model," Journal of Personality and Social Psychology, 56 (4): 586-95.

McEvily, B. \& Tortoriello, M. (2011) Measuring trust in organisational research: Review and recommendations", Journal of Trust Research, Vol. 1 No. 1, pp. 23-63

McKnight, D. H., Choudhury, V., \& Kacmar, C. (2002), "Developing and validating trust measures for e-commerce: An integrative typology". Information Systems Research, Vol. 13 No. 3, pp. 334-359

McKnight, D. H. and Chervany, N. L. (2001-2002) What Trust Means in E-Commerce Customer Relationships: An Interdisciplinary Conceptual Typology. International Journal of Electronic Commerce 6 (2): 35-59. 
McKnight, D. H., Cummings, L. L. and Chervany, N. L. (1998) Initial trust formation in new organisational relationship. Academy of Management Review 23(3): 473 -490.

Moin, S. M. A., Devlin, J., and McKechnie, S. (2015) Trust in financial services: Impact of institutional trust and dispositional trust on trusting belief. Journal of Financial Services Marketing, 20 (2): 91-106.

Moin, S. M. A., Devlin. J., McKechnie. S. (2016) "Magic of Branding: The role of 'Pledge', 'Turn' and 'Prestige' in Fostering Consumer Trust in Financial Services. Journal of Financial Services Marketing, Journal of Financial Services Marketing, 22 (2): 113 -126.

Morrison, S. and Crane, F. (2007) Building the service brand by creating and managing an emotional brand experience. Journal of Brand Management 14 (5): 410-421.

Moorman, C, Deshpande, R. and Zaltman, G. (1993), "Factors affecting trust in market research relationships". Journal of Marketing. 57: 81 - 101

Moorman, C, Zaltman, G, \& Deshpande, R. (1992), "Relationships between providers and users of market research: The dynamics of trust within and between organizations". Journal of Marketing Research. Vol. 29, pp. 314-328

Morgan, R.M. and Hunt, S.D. (1994), "The commitment-trust theory of relationship marketing”. Journal of Marketing. 58: 20-38

Nienaber, Ann-Marie, Hofeditz, M. and Searle, R.H. (2014) Do we bank on regulation or reputation? A meta-analysis and meta-regression of organizational trust in the financial services sector, International Journal of Bank Marketing, 32 (5): 367 -407.

Nunnally, J. C. (1978). "Psychometric theory” (2nd ed.). New York: McGraw-Hill

Ping Li, P. (2007) Towards an Interdisciplinary Conceptualization of Trust: A Typological Approach. Management and Organization Review, 3 (3): 421- 445.

Punj, Girish, and David W. Stewart. (1983) "Cluster Analysis in Marketing Research: Review and Suggestions for Application." Journal of Marketing Research, vol. 20, no. 2, pp. 134148. www.jstor.org/stable/3151680.

Rotter, J. B. (1967) A new scale for the measurement of interpersonal trust. Journal of Personality 35 (4): 651-665.

Rousseau, D.M., Sitkin, S.B., Burt, R.S. and Camerer, C. (1998). "Not so different after all: A cross discipline view of trust", Academy of Management Review, Vol. 23 No. 3, pp.393-104

Scott, W. R. (1995), "Institutions and Organizations". Thousand Oaks, CA: Sage

Sekhon, H., Roy, S. Shergill, G. and Pritchard, A. (2013). Modelling trust in service relationships: a transnational perspective. Journal of Services Marketing, 27 (1): 76 - 86

Sekhon, H., Ennew, C., Kharouf, H., \& Devlin, J. (2014). Trustworthiness and trust: influences and implications. Journal of Marketing Management, 30 (3-4), 409-430

Sitkin, S.B. and Roth, N. L. (1993), "Explaining the Limited Effectiveness of Legalistic 'Remedies' for Trust/Distrust". Organization Science, Vol. 4, pp. 368, 373

Tan, F. B. and Sutherland, P. (2004) Online Consumer Trust: A Multi-Dimensional Model. Journal of Electronic Commerce in Organizations 2(3): 40-58. 
Tyler, K. and Stanley (2007) The role of trust in financial services business relationships. Journal of Services Marketing 21(5): 334 - 344.

Uslaner, E. (2002). The Moral Foundations of Trust, Cambridge: Cambridge University Press.

Zaheer, A. and Harris, J. (2006) Interorganizational trust. In O. Shenkar and J.J. Reurer (Eds.), Handbook of strategic alliances: 169-97, Thousand Oaks, Calif: Sage.

Zand, D. E. (1972), "Trust and management problem solving", Administrative Science Quarterley, 17: $229-239$. 
AM2016 Special Issue

\section{Trust in Financial Services: The Influence of Demographics and Dispositional Characteristics}

Table 1: Summary of Sample Profile

\begin{tabular}{lll}
\hline & Frequency & Percent (\%) \\
\hline Cluster & & \\
$\quad$ Cluster 1 (High trust group) & 171 & 57.0 \\
$\quad$ Cluster 2 (Low trust group) & 129 & 43.0 \\
Gender & & \\
Male & 94 & \\
Female & 205 & \\
Missing & 1 & \\
Marital Status & 179 & 59.7 \\
Single & 87 & 29.0 \\
Married or with partnership & 12 & 4.0 \\
Divorced & 22 & 7.3 \\
Preferred not to say & & \\
Age & 106 & 35.3 \\
25 and under & 112 & 37.3 \\
26-35 & 71 & 23.7 \\
36 and over & 11 & 3.7 \\
Missing & & \\
Ethnicity & 163 & 54.3 \\
White: British and Other & 77 & 25.7 \\
South Asian: India, Pakistan and Bangladesh & 35 & 11.7 \\
Black and Other & 25 & 8.3 \\
Missing & & \\
Gross Annual Income & 138 & 46.0 \\
Up to £30,000 & 51 & 17.0 \\
£30,001 - £50,000 & 45 & 15.0 \\
Over £50,000 & & \\
\hline
\end{tabular}


Table 2: Measurement Scale

\begin{tabular}{|c|c|c|}
\hline $\begin{array}{l}\text { Main } \\
\text { Constructs }\end{array}$ & Sub-constructs & Variables \\
\hline *Trusting & Integrity and & My bank keeps its word \\
\hline \multirow[t]{18}{*}{ Belief } & Competency & My bank shows high integrity \\
\hline & & My bank is honest \\
\hline & & My bank conducts transactions fairly \\
\hline & & My bank is consistent in what it does \\
\hline & Concern and & My bank can be relied upon for honest advice \\
\hline & Benevolence & My bank shows respect for the customer \\
\hline & & My bank treats customers fairly \\
\hline & & My bank is receptive to my needs \\
\hline & Shared Values & My bank has the same concerns as me \\
\hline & & My bank has the same values as me \\
\hline & & My bank acts as I would \\
\hline & Expertise and & My bank has the information it needs to conduct its business \\
\hline & competence & My bank competently handles all my requests \\
\hline & & My bank is efficient \\
\hline & & My bank is knowledgeable \\
\hline & Communication & My bank informs me immediately of any problems \\
\hline & & My bank informs me immediately of new developments \\
\hline & & My bank communicates regularly \\
\hline \multirow{9}{*}{$\begin{array}{l}* * \text { Institutional } \\
\text { Trust }\end{array}$} & Structural & I am confident that existing policies and regulations protect \\
\hline & Assurance & customers of financial services institutions \\
\hline & & I have faith and confidence in the financial system \\
\hline & & $\begin{array}{l}\text { I generally trust financial institutions to act honestly and } \\
\text { ethically }\end{array}$ \\
\hline & & I trust financial institutions to stick to rules and regulations \\
\hline & & $\begin{array}{l}\text { I trust all financial institutions to ensure that their employees } \\
\text { are well trained and professional }\end{array}$ \\
\hline & Situational & I expect the government-appointed authorities to ensure that \\
\hline & Normality & financial institutions behave themselves \\
\hline & & $\begin{array}{l}\text { I expect the government-appointed authorities to take } \\
\text { complaints about financial institutions seriously }\end{array}$ \\
\hline \multirow{9}{*}{$\begin{array}{l}* * \text { Dispositional } \\
\text { Trust }\end{array}$} & Faith in Humanity & In general, I trust people that I meet \\
\hline & & In general, I like to give people the benefit of the doubt \\
\hline & & I think that people are generally honest in their dealings \\
\hline & & $\begin{array}{l}\text { I usually trust people until they give me a reason not to trust } \\
\text { them }\end{array}$ \\
\hline & & $\begin{array}{l}\text { I generally give people the benefit of the doubt when I first } \\
\text { meet them }\end{array}$ \\
\hline & & $\begin{array}{l}\text { My typical approach is to trust new acquaintances until they } \\
\text { prove I should not trust them }\end{array}$ \\
\hline & Trusting Stance & In general, I trust what I read in the newspapers \\
\hline & & In general, I trust the news provided by TV channels \\
\hline & & In general, I trust supermarkets \\
\hline \multicolumn{3}{|c|}{$\begin{array}{l}\text { Source: *Adapted from Ennew et al }(2011) \text { and } * * \text { developed from interdisciplinary trust literature } \\
\text { (McKnight et al, 1998; McKnight and Chervany, 2001-02; Mayer et al, 1995) }\end{array}$} \\
\hline
\end{tabular}


Table 3: Summary of the Results of Exploratory Factor Analysis (EFA)

\begin{tabular}{|c|c|c|c|c|c|c|}
\hline Main Constructs & $\begin{array}{l}\text { Factors loading under the } \\
\text { sub-dimensions }\end{array}$ & $\begin{array}{l}\text { Number of } \\
\text { variables } \\
\text { loaded }\end{array}$ & Correlation coefficients between variables & $\begin{array}{l}\text { Cronbach's } \\
\text { Alpha }\end{array}$ & $\begin{array}{l}\% \text { of variance } \\
\text { explained }\end{array}$ & $\begin{array}{ll}\text { Total \% of } \\
\text { variance } \\
\text { explained }\end{array}$ \\
\hline \multirow[t]{5}{*}{ Trusting Belief } & Integrity and Consistency & 5 & $0.818,0.764,0.779,0.732,0.748$ & 0.950 & 22.735 & \multirow[t]{5}{*}{$\underline{84.408}$} \\
\hline & Concern and Benevolence & 4 & $0.620,0.705,0.657,0.691$ & 0.940 & 13.832 & \\
\hline & Shared Values & 3 & $0.871,0.866,0.868$ & 0.919 & 15.382 & \\
\hline & Expertise and Competence & 4 & $0.821,0.756,0.688,0.776$ & 0.926 & 17.656 & \\
\hline & Communication & 3 & $0.759,0.837,0.839$ & 0.896 & 14.803 & \\
\hline \multirow[t]{2}{*}{ Institutional Trust } & Structural Assurance & 6 & $0.597,0.698,0.856,0.896,0.899,0.725$ & 0.903 & 22.859 & \multirow[t]{4}{*}{$\underline{71.041}$} \\
\hline & Situational Normality & 2 & $0.828,0.851$ & 0.886 & 11.526 & \\
\hline \multirow[t]{2}{*}{ Dispositional Trust } & Faith in Humanity & 6 & $0.709,0.804,0.699,0.759,0.847,0.807$ & 0.892 & 21.657 & \\
\hline & Trusting Stance & 3 & $0.832,0.879,0.819$ & 0.871 & 15.00 & \\
\hline
\end{tabular}


Table 4: Construct Correlation and Measurement Properties

\begin{tabular}{|c|c|c|c|c|c|c|c|c|c|c|}
\hline \multirow[b]{2}{*}{ Constructs } & \multicolumn{5}{|c|}{ Trusting Belief (TBLF) } & \multirow{2}{*}{$\begin{array}{l}\text { Trusting } \\
\text { Intention } \\
\text { (TINT) }\end{array}$} & \multicolumn{2}{|c|}{$\begin{array}{l}\text { Institutional } \\
\text { Trust }\end{array}$} & \multicolumn{2}{|c|}{$\begin{array}{l}\text { Dispositional } \\
\text { Trust }\end{array}$} \\
\hline & $\mathrm{IC}$ & $\mathrm{CB}$ & SV & $\mathrm{EC}$ & COMM & & SA & $\mathrm{SN}$ & $\mathrm{FH}$ & TS \\
\hline $\mathrm{IC}$ & 1 & & & & & & & & & \\
\hline CB & 0.879 & 1 & & & & & & & & \\
\hline SV & 0.584 & 0.597 & 1 & & & & & & & \\
\hline $\mathrm{EC}$ & 0.766 & 0.798 & 0.467 & 1 & & & & & & \\
\hline COMM & 0.62 & 0.67 & 0.48 & 0.733 & 1 & & & & & \\
\hline *TINT & 0.695 & 0.723 & 0.502 & 0.745 & 0.672 & 1 & & & & \\
\hline SA & 0.436 & 0.433 & 0.436 & 0.367 & 0.422 & 0.379 & 1 & & & \\
\hline $\mathrm{SN}$ & 0.396 & 0.401 & 0.185 & 0.428 & 0.322 & 0.407 & 0.454 & 1 & & \\
\hline FH & 0.434 & 0.426 & 0.199 & 0.334 & 0.333 & 0.417 & 0.296 & 0.33 & 1 & \\
\hline $\mathrm{TS}$ & 0.265 & 0.235 & 0.245 & 0.093 & 0.123 & 0.227 & 0.385 & 0.105 & 0.478 & 1 \\
\hline CR & 0.951 & 0.942 & 0.921 & 0.926 & 0.898 & 0.952 & 0.899 & 0.888 & 0.892 & 0.874 \\
\hline AVE & 0.794 & 0.802 & 0.797 & 0.758 & 0.746 & 0.693 & 0.646 & 0.799 & 0.581 & 0.699 \\
\hline $\begin{array}{l}\text { Root Square } \\
\text { of } A V E\end{array}$ & 0.891 & 0.896 & 0.893 & 0.871 & 0.864 & 0.832 & 0.804 & 0.894 & 0.762 & 0.836 \\
\hline Model Fit & $\begin{array}{l}\text { Chi-Sc } \\
0.970 \text {, }\end{array}$ & $\begin{array}{l}\text { ared }(\chi \\
\mathrm{FI}=0 .\end{array}$ & $\begin{array}{l}=22 \\
\mathrm{CF}\end{array}$ & $\begin{array}{l}05(p= \\
0.972, G\end{array}$ & $\begin{array}{l}00), \mathrm{df}= \\
=0.732\end{array}$ & $856, \chi^{2}$ & $63, \mathrm{R}$ & SEA & 0.077, & $\mathrm{NNFI}=$ \\
\hline
\end{tabular}


Table 5: Measurement of Trust

\begin{tabular}{llll}
\hline Types of Trust & Dimensions & Cluster 1 & Cluster 2 \\
\hline Dispositional Trust & Faith in Humanity & 3.94 & 5.18 \\
& Trusting Stance & 2.51 & 4.60 \\
\hline Institutional Trust & Structural Assurance & 3.50 & 4.94 \\
& Situational Normality & 3.82 & 6.08 \\
\hline
\end{tabular}

Table 6: General Disposition to Trust and Trusting Belief

\begin{tabular}{llllll}
\hline & $\begin{array}{l}\text { General disposition } \\
\text { to trust }\end{array}$ & $\mathbf{N}$ & Mean & SD & Sig \\
\hline Integrity & Low & 129 & 4.51 & 1.26 & 0.000 \\
and Competency & High & 171 & 5.14 & 1.18 & \\
\hline Concern & Low & 129 & 4.41 & 1.42 & 0.000 \\
and Benevolence & High & 171 & 5.05 & 1.13 & \\
\hline Shared Values & Low & 129 & 3.44 & 1.37 & 0.000 \\
& High & 171 & 4.06 & 1.27 & \\
\hline Expertise & Low & 129 & 4.87 & 1.36 & 0.008 \\
and Competence & High & 171 & 5.26 & 1.14 & \\
\hline Communication & Low & 129 & 4.57 & 1.49 & 0.004 \\
& High & 171 & 5.04 & 1.30 & \\
\hline
\end{tabular}

Table 7: Trust in the System (Institutional Trust) and Trusting Belief

\begin{tabular}{llllll}
\hline & $\begin{array}{l}\text { Trust in the } \\
\text { System }\end{array}$ & N & Mean & SD & Sig \\
\hline Integrity & Low & 110 & 4.29 & 1.41 & 0.000 \\
and Competency & High & 190 & 5.21 & 1.03 & \\
\hline Concern & Low & 110 & 4.20 & 1.43 & 0.000 \\
and Benevolence & High & 190 & 5.11 & 1.09 & \\
\hline Shared Values & Low & 110 & 3.43 & 1.24 & 0.000 \\
& High & 190 & 4.01 & 1.37 & \\
\hline Expertise & Low & 110 & 4.51 & 1.46 & 0.000 \\
and Competence & High & 190 & 5.43 & .98 & \\
\hline Communication & Low & 110 & 4.23 & 1.45 & 0.000 \\
& High & 190 & 5.19 & 1.26 & \\
\hline
\end{tabular}

Table 8: Gender and Trusting Belief

\begin{tabular}{|c|c|c|c|c|c|}
\hline & Gender & $\mathbf{N}$ & Mean & SD & Sig \\
\hline \multirow{2}{*}{$\begin{array}{l}\text { Integrity } \\
\text { and Competency }\end{array}$} & Male & 94 & 4.83 & 1.27 & 0.707 \\
\hline & Female & 205 & 4.89 & 1.26 & \\
\hline \multirow{2}{*}{$\begin{array}{l}\text { Concern } \\
\text { and Benevolence }\end{array}$} & Male & 94 & 4.79 & 1.23 & 0.913 \\
\hline & Female & 205 & 4.77 & 1.34 & \\
\hline \multirow[t]{2}{*}{ Shared Values } & Male & 94 & 3.74 & 1.31 & 0.640 \\
\hline & Female & 205 & 3.82 & 1.37 & \\
\hline \multirow{2}{*}{$\begin{array}{l}\text { Expertise } \\
\text { and Competence }\end{array}$} & Male & 94 & 5.06 & 1.21 & 0.767 \\
\hline & Female & 205 & 5.10 & 1.28 & \\
\hline \multirow[t]{2}{*}{ Communication } & Male & 94 & 4.72 & 1.30 & 0.322 \\
\hline & Female & 205 & 4.89 & 1.46 & \\
\hline
\end{tabular}


Table 9: Summary of Output of ANOVA: Age and Trusting Belief

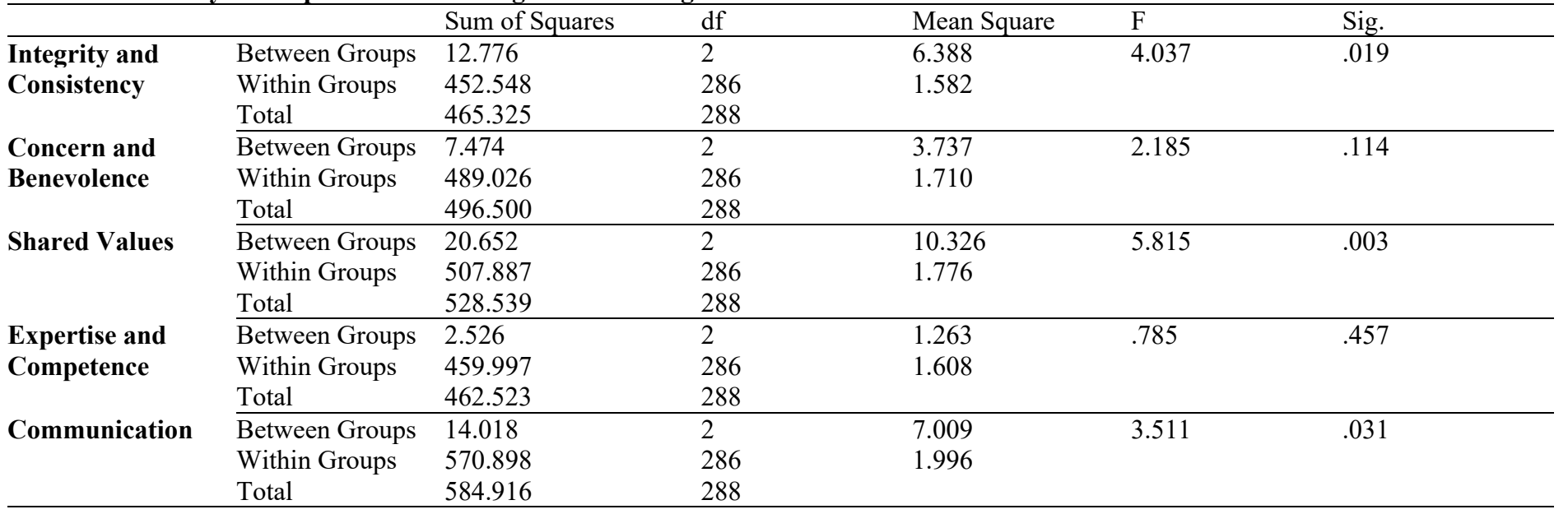


Table 10: Summary of Output of ANOVA: Marital Status and Trusting Belief

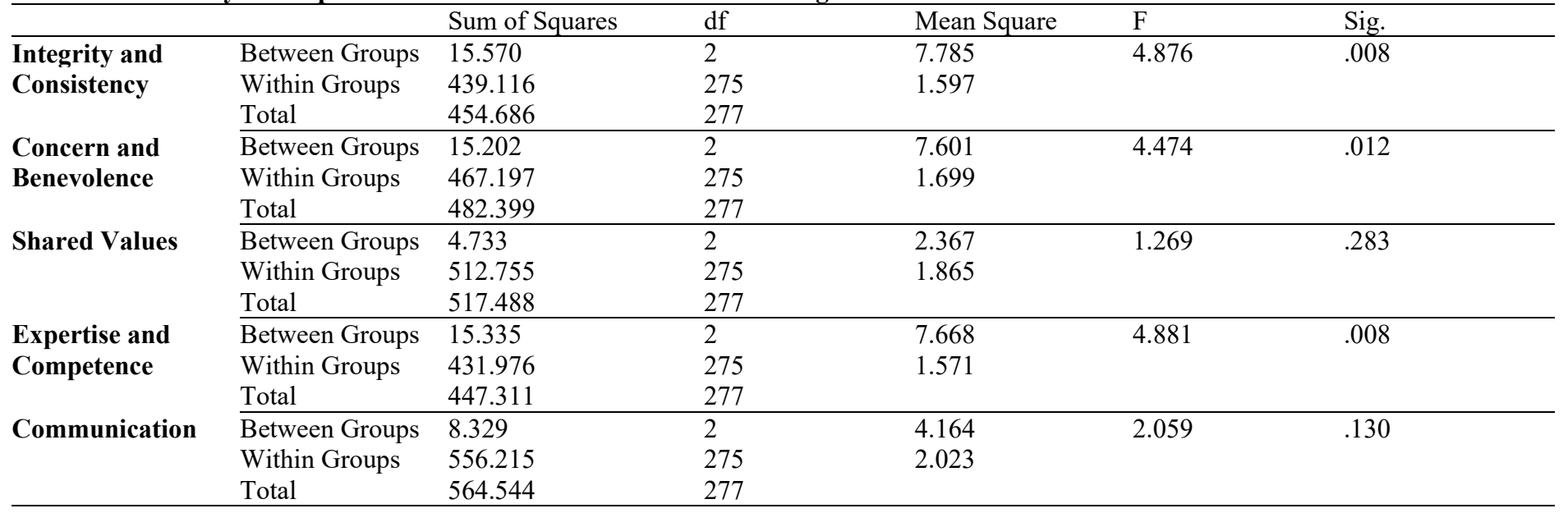


Table 11: Summary of Output of ANOVA: Ethnicity and Trusting Belief

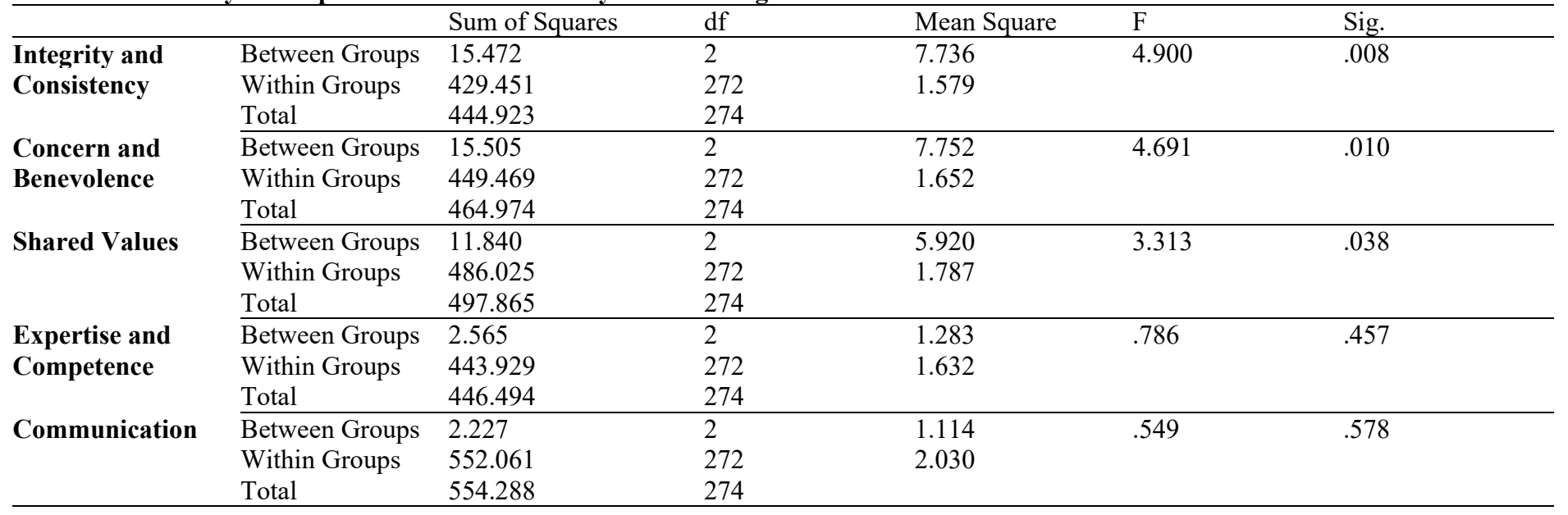


Table 12: Summary of Output of ANOVA: Income and Trusting Belief

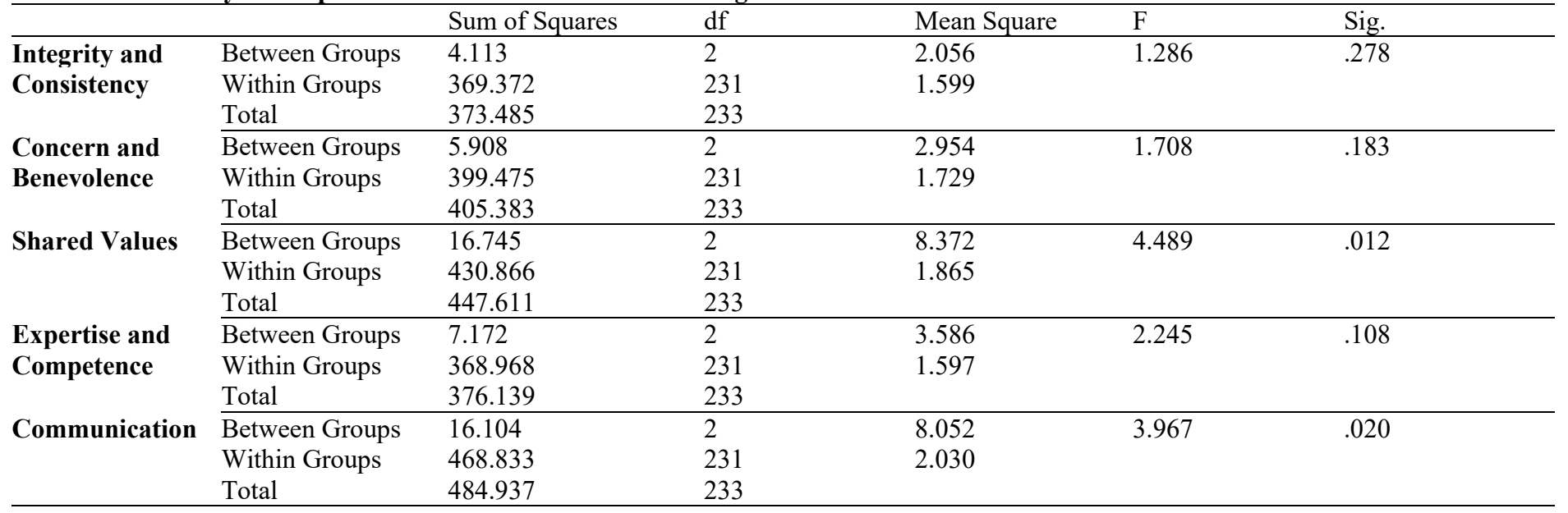

